\title{
A pension for injured victims of the Troubles: reparations or reifying victim hierarchy?
}

\author{
LUKE MOFFETT
}

Queen's University Belfast*

\begin{abstract}
$\underline{\text { Abstract }}$
Reparations have been often-used victim-centred measures to redress both private harm and gross violations of human rights. However, with the increasing occurrence of internal armed conflict and political violence, identities of victims and perpetrators in protracted conflicts can become blurred for some individuals. In countries like Peru and Northern Ireland that have suffered protracted violence, victimbood has been contested around which individuals are seen as innocent and deserving in order to exclude any members of non-state armed groups from claiming reparations. This article explores the issue of a proposed Bill on a pension for injured victims of the Troubles in Northern Ireland. It identifies that there is no consistent state practice or human rights jurisprudence in this area, but instead offers a more complex approach through four models that can grapple with the seeming diametrically opposed victimhood and responsibility, by including victimised perpetrators in reparations programmes such as that proposed for a pension for seriously injured victims in Northern Ireland.
\end{abstract}

\section{Introduction}

$\mathrm{D}$ ealing with the past in the aftermath of protracted violence or conflict is never easy, but defining who is a victim and who deserves reparations is a recurring challenge. The past three decades have seen a global proliferation of transitional justice mechanisms, including truth commissions, amnesties and reparations. Such mechanisms have not yet taken root in Northern Ireland and were noticeably inconspicuous in the 1998 Good Friday Agreement - more a peace agreement than a transitional justice roadmap for dealing with the consequences of the past. Although many victim and civil society groups in Northern Ireland have advocated for truth and justice, ${ }^{1}$ such efforts have only crystallised after successive judgments at the European Court of Human Rights (ECtHR), in particular for contentious deaths involving state forces under Article 2 of the European Convention on Human Rights on the right to life. As a result, institutions such as the Historical Enquiries Team were created and ordinary mechanisms like the coronial courts were reformed, but these were subsequently found to be inadequate in terms of both promptness and

* Many thanks to Anna Bryson and Kieran McEvoy for their very helpful comments on this article.

1 One particularly effective victim group has been for those whose family members were disappeared by republican paramilitaries resulting in the establishment of the Independent Commission for the Location of Victims' Remains. See Lauren Dempster, 'The Republican Movement, "Disappearing", and Framing the Past in Northern Ireland' (forthcoming) International Journal of Transitional Justice. 
independence. Recent negotiations and agreements such as the 2014 Stormont House Agreement have reinforced the attention to truth and justice for those who were killed during the Troubles, but with little attention to reparations.

The focus on Article 2 compliance has ensured that discussions on the past have focused on deaths. This arguably narrows attention paid to victims of other crimes, such as sexual violence, physical assault and torture. Indeed, a significant constituency left out of the equation on the past are the 40,000 individuals who were injured during the Troubles, many of them seriously. The suffering of those seriously injured is worsening as they are getting older, requiring carers and mobility assistance, being unable to work and build up a pension, and thus being dependent on state benefits or the support of friends and families. The passage of time has compounded their problems because many suffer increasing physical distress as a result of deteriorating health and chronic pain. Discussion of reparations has become a particularly controversial subject in Northern Ireland, going to the heart of narratives of the past of who is a victim and who is responsible for their harm. This has seen protests in the past, with compensation for killed paramilitaries labelled as 'blood money' or the 'wages of murder'. ${ }^{2}$ The Democratic Unionist Party (DUP) has stated that, based on its consultation, the opinion of the 'vast majority of innocent victims is that they would rather there be no pension provision than for perpetrators to benefit'. ${ }^{3}$ The 2014 Stormont House Agreement rather blandly stated that further work will be 'undertaken to seek an acceptable way forward on the proposal for a pension for severely physically injured victims in Northern Ireland'. ${ }^{4}$ Given the ongoing impasse on the broader issues related to truth and justice, the pension is now the only new process moving forward with DUP MLA Brenda Hale introducing a Private Members' Bill on the issue, perhaps as a cynical attempt to be 'seen' to do something about the past.

This article examines the role of a proposed pension Bill for seriously injured victims as a form of reparations. In particular it tries to unpack some of the contentious elements of victimhood and responsibility around who should be eligible for such a pension. It begins by briefly outlining the purpose of reparations in international law before discussing in more depth the controversy around contested identities and how other states have addressed the issue of victimised perpetrators and the difficulties this has created in regional human rights courts. In particular this first section explores the private law basis of reparations in international law, legal provisions in states dealing with victimised perpetrators and the jurisprudence of human rights courts in reconciling principles of non-discrimination and remedy with responsibility of victimised perpetrators. The second section discusses the Northern Ireland experience with financial reparations, noting the shortcomings in past compensation arrangements and the current prevailing service-based approach, before briefly outlining the proposed pension for seriously injured victims. The final section explores possible avenues and definitions that may help to traverse the difficult political landscape of victimised perpetrators' eligibility for a pension.

2 Owen Bowcott, 'Protests Disrupt Launch of Northern Ireland Troubles Payout Proposals' The Guardian (London, 28 January 2009).

3 DUP, 'We'd Rather Sink Pensions Scheme than See Terrorists Get Cash' Newsletter (20 March 2015).

4 Para 28. 


\section{Reparations in international law}

Reparations in international law are based in private law principles of seeking to return the victim to the status quo ante (original position) through restitutio in integrum (returning to the victim all they have lost), echoing equity and tort principles in domestic jurisdictions. ${ }^{5}$ This is a form of rectificatory or corrective justice that attempts to restore the equality between the injured and responsible party, through imposing a proportional penalty on the perpetrator commensurate to the harm caused so as to benefit the injured party. ${ }^{6}$ In international law the underlying principle for reparations is to 'as far as possible, wipe-out all the consequences of the illegal act and re-establish the situation which would, in all probability, have existed if that act had not been committed'. ${ }^{7}$ Reparations, at least in human rights law, are intended to acknowledge the harm suffered by victims and to induce those responsible to provide appropriate remedies.

In the face of collective violence it is, of course, almost impossible to devise legal mechanisms that can deal fully with the consequence of such acts and hold all responsible to account. Moreover, returning a victim to their original position may put them back to a marginalised position, without tackling the causes of victimisation. ${ }^{8}$ Instead, the purpose of reparations involves focusing upon attempting to improve life opportunities and quality of life for victims in ways that privilege their agency and choice through compensation and rehabilitation. ${ }^{9}$ In addition, preventing the recurrence of violations is, of course, a key concern of international law. Such preventative measures involve 'making real' the guarantees of non-repetition which are a cornerstone of international human rights law. In practice, this may entail a range of measures, including institutional reform and redressing the structural causes of victimisation, as well as measures of satisfaction which publicly acknowledge and memorialise the victims' suffering, such as apologies, memorials and truth recovery processes, so that they can 'awaken ... public awareness to avoid repetition' and 'maintain remembrance of the victim'. ${ }^{10}$ In light of these limits, human rights law has over the past few decades developed five types of reparations to effectively remedy gross violations of human rights: restitution, compensation, rehabilitation, measures of satisfaction and guarantees of non-repetition. ${ }^{11}$

A further difficulty with reparations in international law and more political constructions in transitional justice is that they reflect a state-centric approach based on

5 Velásquez. Rodríguez v Honduras, Judgment of 21 July 1989 (Reparations and Costs), paras 25-26; and Papamichalopoulos and Others v Greece, Application No 14556/89) ECtHR Judgment of 31 October 1995, para 34. Dinah Shelton, Remedies in International Human Rights Law (OUP 2005) 9 and 65.

6 Aristotle, Nicomechean Ethics, Book V; and William T Blackstone, 'Reverse Discrimination and Compensatory Justice' (1975) 3(3) Social Theory and Practice 253-88.

7 Germany v Poland, The Factory at Chorzow (Claim for Indemnity) (The Merits), Permanent Court of International Justice, File E c XIII, Docket XIV:I Judgment No 13, 13 September 1928, para 125.

8 Heidi Rombouts and Stephan Parmentier, 'The International Criminal Court and its Trust Fund are Coming of Age: Towards a Process Approach for the Reparation of Victims' (2009) 16 International Review of Victimology 149-82.

9 Such as the proyecto de vida (life project) reasoning recognised for a time by the Inter-American Court of Human Rights in Loayza Tamayo v Peru, Reparations and Costs, Judgment of 27 November 1998, Series C No 42, paras 147-48.

10 Principle 22, UNBPG; 19 Tradesmen v Colombia, Merits, Reparations and Costs, Series C No 109 (InterAmerican Court of Human Rights, 5 July 2004), paras 272-73; Myrna Mack-Chang v Guatemala, Merits, Reparations and Costs, Series C No 101 (Inter-American Court of Human Rights, 25 November 2003), para 286.

11 See UNBPG on the Right to a Remedy and Reparation for Victims of Gross Violations of International Human Rights Law and Serious Violations of International Humanitarian Law 2005, A/RES/60/147. 
the state both as the main violator and as the entity with the greatest responsibility for reparations. This is problematic for Northern Ireland, given that 'perpetrators' include both non-state and state actors and, leaving aside the issue of state collusion, the nonstate actors were responsible for approximately 90 per cent of all fatalities. ${ }^{12}$ Moreover, it means that members of non-state armed groups, such as the Irish Republican Army (IRA), Ulster Defence Association and Ulster Volunteer Force, were victimised by other groups, but also subject to torture, inhuman and degrading treatment as well as extrajudicial killings (the so-called 'shoot to kill' policy), both directly and through state collusion with paramilitary organisations. ${ }^{13}$ This complex reality of violence and human rights abuses speaks directly to the limitations of what McEvoy and McConnachie have described as 'monochromatic distinctions between universally innocent victims and guilty perpetrators'. ${ }^{14}$ As reparations programmes seek to demarcate and quantify forms of harms and victims as deserving of redress through definitions, such programmes become enmeshed in the political contests surrounding victimhood.

\section{VICTIM HIERARCHIES IN CONFLICT AND TRANSITION}

Victimhood can be fiercely disputed in times of conflict and transition to peace. Combatants in armed conflicts can often portray themselves as collective victims and the 'good guys', innocent of any crime and deserving of sympathy and support. ${ }^{15}$ This is apparent in the Israeli/Palestinian conflict. ${ }^{16}$ The use of 'innocent' or 'real' identification of victims within conflicts and post-conflict societies perpetuates very powerful moral conceptions of victimhood. ${ }^{17}$ Given that collective violence is prolonged and multifaceted, simplistic black and white understandings of perpetrators and victims rarely neatly map onto the real world of conflicted and transitional societies. ${ }^{18}$ Instead, the 'messy' reality of these conflicts can mean that there are complex identities of victimised perpetrators, such as child soldiers. ${ }^{19}$ It is only through understanding this 'thicker' multiperspective of victimisation for collective violence that we can begin to develop the law to effectively redress such harms. ${ }^{20}$

Reparations represent both a symbolic acknowledgment of an individual's victimhood and some form of remedial benefit. The remedial nature of reparations can come into

12 Malcolm Sutton, Bear in Mind these Dead . . . An Index of Deaths from the Conflict in Ireland 1969-1993 (Beyond the Pale Publications 1994); and David McKittrick, Seamus Kelters, Chris Thornton, Brian Feeney and David McVea, Lost Lives: The Stories of the Men, Women and Children Who Died as a Result of the Northern Ireland Troubles (Mainstream Publishing 2004).

13 See Anne Cadwallader, Lethal Allies: British Collusion in Ireland (Mercier Press, 2013); Sir Desmond de Silva QC, Report of the Patrick Finucane Review (TSO December 2012); and Brice Dickson, The European Convention on Human Rights and the Conflict in Northern Ireland (OUP 2010) 167.

14 Kieran McEvoy and Kirsten McConnachie, 'Victimology in Transitional Justice: Victimhood, Innocence and Hierarchy' (2012) 9(5) European Journal of Criminology, 527-38, 534.

15 Mike Morrissey and Marie Smith, Northern Ireland after the Good Friday Agreement: Victims, Grievance and Blame (Pluto Press 2002) 5; and Luc Huyse, 'Victims' in D Bloomfiled, T Barnes and L Huyse (eds), Reconciliation after Violent Conflict: A Handbook (IDEA 2002) 54-65, 62.

16 See David Bar-Tal, Lily Chernyak-Hai, Noas Schori and Ayelet Gundar, 'A Sense of Self-Perceived Collective Victimhood in Intractable Conflicts' (June 2009) 91 (874) International Review of the Red Cross 229-58.

17 Erica Bouris, Complex Political Victims (Kumarian 2007); and Morrissey and Smith (n 15).

18 Collective violence is used here to cover gross violations of human rights, crimes against humanity and genocide.

19 Kieran McEvoy and Kirsten McConnachie, 'Victims and Transitional Justice: Voice, Agency and Blame' (2014) 22(4) Social and Legal Studies 489-513, 494.

20 Kieran McEvoy, 'Beyond Legalism: Towards a Thicker Understanding of Transitional Justice' (2007) 34(4) Journal of Law and Society 411-40. 
immediate conflict with the definition of victims/perpetrators and the associated political discourses concerning who is seen as deserving. This can threaten to unsettle fragile and long-term peace processes, such as in Peru and Northern Ireland, where provisions for victimised perpetrators to receive reparations have been met with protests and condemnation. As a result a 'hierarchy of victims' can arise, in which 'innocent' or 'real' victims are prioritised to facilitate the appropriation of blame and innocence in political narratives of past conflict. ${ }^{21}$ Such moral gradation can feed competition for recognition amongst victims, influence decisions regarding material resources or symbolic gestures, such as monuments, and can potentially exclude less deserving individuals like victimised perpetrators. ${ }^{22}$ As McEvoy and McConnachie argue, 'the innocent' victim is placed at the 'apex of a hierarchy of victimhood and becomes a symbol around which contested notions of past violence and suffering are constructed and reproduced'. ${ }^{23}$

Victims who are responsible for their own suffering or that of others have been a concern of victimology since its earliest iterations in positivist criminology through accounts which emphasised the victim's actions, characteristics, or circumstances that precipitated or provoked the perpetrator to commit an offence. ${ }^{24}$ Predictably, such 'victim blaming' caused a significant backlash amongst critical and feminist criminologists. For example, Christie's memorable description of the 'ideal victim' as 'an innocent, vulnerable, good citizen, who has been attacked by a big, bad offender' has had a longstanding resonance in domestic and international victimology. 25 This construction of the 'innocent victim' serves to contrast the 'wicked' perpetrator or terrorist who deserves punishment. ${ }^{26}$ More critical accounts of victimhood examine the 'role of the law and the state in the victimisation process as well as the potential for human actors both to sustain and to change the conditions under which they act'. ${ }^{27}$ A critical understanding of victimhood exhibits the socio-political context whereby, in the real world, individuals are not always recognised as victims, owing to prevailing political or moral 'labelling' of who a victim should be and who deserves recognition. ${ }^{28}$ Through this perspective the concern for recognition and fair treatment of victims better reflects the relational or 'lived reality' of individuals and groups that suffer as a result of a crime, but it perhaps neglects the responsibility of some victims' in their own harm and that of others. ${ }^{29}$

In relation to victimised perpetrators, McAlinden has identified a 'continuum of offending' where victims are coerced or cooperate to facilitate perpetrator violence to avoid further suffering themselves and/or to survive. ${ }^{30}$ Making victims complicit or collaborators in the victimisation process can have the effect of further dehumanising them. A pertinent example is provided by those Jews who were used as 'special squads'

21 See Bouris (n 17); and McEvoy and McConnachie (n 14) 532.

22 Huyse (n 15) 64.

23 McEvoy and McConnachie (n14) 532.

24 See Hans Von Hentig, The Criminal and his Victim: Studies in the Socio-Biology of Crime (Archon 1967); and Martin F Wolfgang, 'Victim Precipitated Criminal Homicide' (1957) 48(1) Journal of Criminal Law and Criminology $1-11$.

25 See Nils Christie, 'Conflicts as Property' (1977) 17(1) British Journal of Criminology 1-15, 19.

26 David Becker, Elizabeth Lira, Maria Isabel Castillo, Elena Gomez and Juana Kovalskys, 'Therapy with Victims of Political Repression in Chile: The Challenge of Social Reparation' (1990) 46 (3) Journal of Social Issues 133-49, 135.

27 Rob Mawby and Sandra Walklate, Critical Victimology: International Perspectives (Sage 1994) 177.

28 Richard Quinney, 'Who is the Victim?' (1972) 10 Criminology 314-23, 321.

29 McEvoy and McConnachie (n 14) 530.

30 Anne-Marie McAlinden, 'Deconstructing Victim and Offender Identities in Discourses on Child Sexual Abuse: Hierarchies, Blame and the Good/Evil Dialectic' 54(2) British Journal of Criminology 180-98, 186. 
in Auschwitz to burn the bodies of those who were killed in the gas chambers before later suffering the same fate themselves. In the context of Northern Ireland, most paramilitaries were volunteers and were not coerced, in comparison to those who are forced to commit atrocities, such as child soldiers or special squads. This 'grey zone' of identities counters the simplicity of perpetrators and victims as always being in two distinct blocs. ${ }^{31}$ Such binary construction of victimisation can gloss over issues of responsibility, such as with child soldiers who are forced to commit atrocities, but who may not fit into such a neat category of 'innocent' when they become adults and rise to a position of command. ${ }^{32}$

The focus of this article is on members of armed, paramilitary or terrorist groups, or state forces, who have committed political violence but who have been victimised through identifiable gross violations of human rights law or international crimes, such as disappearances, extrajudicial killings, sexual violence, torture, serious injury, or illtreatment caused by other actors. These crimes are distinguished due to their jus cogens nature as they are considered objectively illegal and can never be justified in their commission in international customary law, no matter the background or association of an individual. ${ }^{33}$ It notably excludes those who have self-inflicted injuries, breaking the causal link of unlawful harmed caused by others. Nonetheless, this article takes a critical victimological approach by recognising that such individuals are victims to avoid acknowledgment becoming a source of victimisation, but also appreciates their responsibility. As such, the law should not exclude those who have been seriously victimised because of their association or past actions, but should adopt a 'thicker' understanding to take into account their role in victimising others and determine what reparations are appropriate for such individuals. Accordingly, while those members of state or non-state armed groups who were seriously victimised should be eligible for reparations, it should also be acknowledged that they were responsible for victimising others and so should be made to contribute to reparations for their victims or have their own forms of reparations limited. The final section of this article discusses the pros and cons of related models. Before advancing to this discussion, it is worth considering the relevant state practice and jurisprudence of regional human rights courts on these issues.

\section{Tackling victimised perpetrators in domestic reparation programmes}

The question of whether victimised perpetrators should be eligible for reparations is not unique to Northern Ireland. In Latin America, countries like Colombia and Peru have suffered from protracted internal armed conflict with violence committed by state and non-state armed groups. In both contexts, victimised perpetrators are ineligible for reparations. In Colombia, the 2011 restitution of land law stipulates that members of illegal armed groups are not considered victims, except for children or adolescents demobilised when they were under $18 .{ }^{34}$ Interestingly, family members of individuals in non-state armed groups are recognised as victims where the person is killed, but not if they are injured. In the case of Peru, the truth commission recognised the harm

31 Primo Levi, The Drowned and the Saved (Abacus 1989) ch 2.

32 McEvoy and McConnachie (n 14) 533. See Erin K Baines, 'Complex Political Perpetrators: Reflections on Dominic Ongwen' (2009) 47(2) Journal of Modern African Studies 163-91.

33 M Cherif Bassiouni, 'International Crimes: Jus Cogens and Obligatio Erga Omnes' (1996) 59 Law and Contemporary Problems 63-74.

34 Article 3(2), 2011 Ley de Víctimas y Restitución de Tierras en Colombia en Contexto. See Cristián Correa, From Principles to Practice: Challenges of Implementing Reparations for Massive Violations in Colombia (International Center for Transitional Justice, October 2015). 
suffered by members of non-state armed groups, such as the Shining Path (Sendero Luminoso) or Túpac Amaru Revolutionary Army (MRTA), but held that they were 'victims, but not beneficiaries' of reparations. ${ }^{35}$ Similarly, the Peruvian reparations law explicitly excludes members of 'subversive groups' from reparations. ${ }^{36}$ However, in both countries, state forces are eligible for reparations, despite being implicated in atrocities. $^{37}$ Similarly, Iraq's 2009 compensation law excluded only those individuals convicted of terrorism offences. ${ }^{38}$ In Spain, members of terrorist groups are excluded from reparations. ${ }^{39}$ Yet, in Basque and Navarre, reparations laws do not explicitly exclude members of terrorist groups. ${ }^{40}$

Other countries have included victimised perpetrators in reparation programmes, including those members of non-state armed groups who have been injured, such as in Sierra Leone or Timor Leste. ${ }^{41}$ In Kosovo, the reparations law includes veterans, martyrs, members of the Kosovo Liberation Army and civilians as being eligible for reparations. ${ }^{42}$ This law is similar to that in Tunisia, reflecting the victory of one side in overthrowing the old regime benefiting their own veterans or 'martyrs' as victims. ${ }^{43}$

In South Africa, the promotion of reconciliation and the end of apartheid defined victims broadly to include those who suffered harm from gross violations of human rights or an act associated with a political objective for which an amnesty was granted. ${ }^{44}$ As noted above, Borer and others have highlighted that this dichotomy did not capture the composite grey zone of identities nor 'perpetrators [who] are simultaneously victims'. ${ }^{45}$ Despite the broad definition of victimisation, numerous victims were excluded from reparations, in particular, those who were victimised by other violations not falling within the defined gross violations of human rights, through harm suffered as a result of acts committed by perpetrators not given an amnesty or that did not amount to a 'political

35 Comisión de la Verdad y Reconciliación (CVR) Report, vol IX, 149, 153. See Rebecca K Root, Transitional Justice in Peru (Palgrave Macmillan 2012) 131.

36 Article 4, Ley que crea el Plan Integral de Reparaciones (PIR), Ley No 285922006.

37 See Luke Moffett, 'Reparations for "Guilty Victims": Navigating Complex Identities of Victim-Perpetrators in Reparation Mechanisms' (forthcoming 2016) International Journal of Transitional Justice.

38 Article 17, 2009 Compensation for those Affected by Military Operations, Military Mistakes and Terrorist Actions, Law No 20.

39 Article 4(3), Law 2/2003.

40 In the Basque country, Decree 107/2012 of 12 June 2012, declaration and reparation for victims of unjust suffering as a result of the violation of their human rights, produced between 1960 and 1978 in the context of politically motivated violence lived in the Community Autonomous Basque (this has been successfully challenged by the Spanish government); and, in Navarre, Regional Law 16/2015 of 10 April 2015, recognition and reparation for victims of politically motivated acts caused by far-right groups or officials.

41 Sierra Leone Truth and Reconciliation Commission Final Report vol II (2004) ch 4, paras 69-70; Timor-Leste Commission for Reception, Truth and Reconciliation, Chega! (2006); Final Report of the Truth, Justice and Reconciliation Commission of Kenya vol IV (2013).

422011 Law No 03/L-054 on the Status and the Rights of the Martyrs, Invalids, Veterans, Members of Kosovo Liberation Army, Civilian Victims and their Families.

43 See Tunisia's 2011 Decree Law No 97 on reparation for the families of the 'martyrs' and wounded persons of the revolution.

44 Truth and Reconciliation Commission Report, vol 1, 86. Promotion of National Unity and Reconciliation Act 34 of 1995 , s 1 .

45 Tshepo Madlingozi, 'Good Victim, Bad Victim: Apartheid’s Beneficiaries, Victims and the Struggle for Social Justice' in W Le Roux (ed), Law, Memory and the Legacy of Apartheid: Ten Years After AZAPO v President of South Africa (Pretoria University Law Press 2007) 107-26, 114, citing Don Foster, Paul Haupt, Marésa de Beer, The Theatre of Violence: Narratives of Protagonists in the South African Conflict (HSRC Press 2005) 4; and Tristan Anne Borer, 'A Taxonomy of Victims and Perpetrators: Human Rights and Reconciliation in South Africa' (2003) 25(4) Human Rights Quarterly 1088-116. 
objective'. ${ }^{46}$ Nevertheless, a number of victimised-perpetrators were recommended by the Truth and Reconciliation Commission for reparations. By way of example, in the case of the three Afrikaner Resistance Movement ${ }^{47}$ members who were murdered by a police officer (who received an amnesty) in Mafikeng in March 1994, the family members of the deceased were recognised as victims and referred to the Reparations and Rehabilitation Committee for consideration. ${ }^{48}$ The picture of victimisation is further clouded by the exclusion of innocent individuals who were wrongly convicted under the apartheid legal system, but who were deemed ineligible for amnesty or reparations. ${ }^{49}$

As such, there remains no consistent state practice on whether victimised perpetrators should be eligible for reparations. Instead eligibility is determined depending on the prevailing political context as to whether reparations can be inclusive, as measures of reconciliation, or exclusive, as measures of justice.

\section{REGIONAL HUMAN RIGHTS COURTS AND VICTIMISED PERPETRATORS}

Regional human rights courts are not immune from the challenge of adjudicating on victimised perpetrators who claim reparations. While the victimised-perpetrator principle of non-discrimination is espoused in human rights treaties and the UN Basic Principles and Guidelines (BPG) on the Right to Remedy and Reparations, the issue of victimised perpetrators has proved more divisive in the jurisprudence of regional human rights courts. ${ }^{50}$ The ECtHR case of McCann $v$ UK, which concerned the shooting dead of three members of the IRA by British special forces in Gibraltar as they were planning to bomb a military parade, provides an interesting example. Although the court ruled that their deaths were a result of unlawful use of force and a violation of Article 2 on the right to life, compensation for families of those killed was deemed inappropriate as, 'the three terrorist suspects who were killed had been intending to plant a bomb in Gibraltar'. ${ }^{51}$

Pellonpää suggests that a better interpretation of the court's decision in McCann is based on legal principles, such as contributory fault (or assumption of risk) that the victims' own acts contributed to their loss. ${ }^{52}$ This could be the application of the equitable doctrine of 'clean hands', which has at times been used by the ECtHR in other cases as a mitigating factor in determining compensation, due to the victim's responsibility or contribution in aggravating their own harm. ${ }^{53}$ Yet, given the serious

46 Mahmood Mamdani, 'Amnesty or Impunity? A Preliminary Critique of the Report of the Truth and Reconciliation Commission of South Africa (TRC)' (2002) 32(3-4) Diacritics 33-59.

47 Afrikaner Weerstandsbeweging, a far right paramilitary Afrikaner group.

48 Application in Terms of s 18 of the Promotion of National Unity and Reconciliation Act No 34 of 1995. Ontlametse Bernstein Menyatsoe Applicant (AM 7498/97), 5 August 1999, involving the deaths of Jacobus Stephanus Uys, Alwyn Wolfaardt and Nicolaas Cornelius Fourie. Borer also gives the example of Winnie Mandela (n 45) 1098-99.

49 Louise Mallinder, Indemnity, Amnesty, Pardon and Prosecution Guidelines in South Africa, Working Paper No 2 (From Beyond Legalism: Amnesties, Transition and Conflict Transformation 2009) 97-98.

50 Article 14, European Convention on Human Rights; Article 2(3), International Covenant on Civil and Political Rights; Article 25, American Convention on Human Rights; and Principle 25, 2005 UNBPG on the Right to Remedy and Reparations.

51 McCann v UK, Application No 18984/91, ECtHR Judgment of 27 September 1995, para 219.

52 Matti Pellonpää, 'Individual Reparation Claims under the European Convention on Human Rights' in A Randelshofer and C Tomuchat (eds), State Responsibility and the Individual: Reparation in Instances of Grave Violations of Human Rights (Martin Nijhoff 1999), 109-24, 112.

53 Heidy Rombouts, Pierto Sardaro, and Stef Vandeginste, 'The Right to Reparation for Victims of Gross and Systematic Violations of Human Rights' in K Feyter, S Parmentier, M Bossuyt and P Lemmens, Out of the Ashes: Reparation for Victims of Gross and Systematic Human Rights Violations (Intersentia 2005) 345-503, 386. For instance, in Beyler v Italy, Application No 33202/96, 28 May 2002. 
nature of violations such as the right to life, the application of contributory fault or the clean hands doctrine is a misapplication of private law principles and undermines the equal protection of individuals under the law.

Since the McCann case, the ECtHR has limited its examination to the state's compliance with procedural obligations, i.e. to effectively investigate such allegations of gross violations, paying less attention to the factual circumstances of the substantive violation of the right to life. This is apparent in the Kelly and Other $v$ UK case where, in facts similar to McCann, eight members of the IRA (and one civilian bystander) were shot by the Special Air Service (SAS) while driving a bomb into a police station in Loughgall. ${ }^{54}$ In the Kelly case, the court did not examine the substantive violation of life, citing ongoing domestic proceedings, and instead found a violation of the procedural obligation to carry out an effective investigation. On this basis, the court awarded compensation to the victims' families due to them suffering 'feelings of frustration, distress and anxiety'. Notably, in contrast to the McCann decision, the court did not engage in determination of the moral worth of those who died by distinguishing terrorists from the civilian bystander. ${ }^{55}$ This is consistent with the ECtHR's proclivity in cases of grave and multiple violations of rights to award compensation due to the serious harm caused to the victims, reflecting private law notions of remedying suffering, rather than moral distinctions. ${ }^{56}$ This can be seen in a more recent statement by the Grand Chamber of the court on the purpose of compensation awards that:

... it [is not] the Court's role to function akin to a domestic tort mechanism court in apportioning fault and compensatory damages between civil parties. Its guiding principle is equity, which above all involves flexibility and an objective consideration of what is just, fair and reasonable in all the circumstances of the case, including not only the position of the applicant but the overall context in which the breach occurred. ${ }^{57}$

However, in subsequent cases involving detention of terrorist members, such as in Del Rio Prada $v$ Spain, the court awarded compensation to a convicted member of the terrorist group ETA for unlawful detention. 58 A distinction could be perhaps drawn between this case and McCann, with the latter involving members of a terrorist organisation in an active operation to carry out a bombing, whereas Del Rio Prada concerned the custody of the state.

In contrast, the Inter-American Court of Human Rights, which has been dealing with decades of state violence, has until very recently generally recognised members of nonstate armed groups as victims eligible for reparations. In one notable case, that of Miguel Castro Castro v Peru, state forces stormed a high security prison which contained a number of members of the rebel group, the Shining Path, resulting in the deaths of 41 female inmates and the injury of 175 others. Added to this, the state subsequently failed to properly investigate claims of extrajudicial executions and ill-treatment. Although the state admitted its partial responsibility for those killed and injured, it was reluctant to

54 Kelly and Others v UK, Application No 30054/96, 4 May 2001.

55 Ibid para 162.

56 See Erdoğan and Others v Turkey, Application No 19807/92, 25 April 2006, para 109; and Yandiyev and Others v Russia, Applications Nos 34541/06, 43811/06 and 1578/07, 10 October 2013.

57 Varnava and Others v Turkey, Applications Nos 16064/90, 16065/90, 16066/90, 16068/90, 16069/90, 16070/90, 16071/90, 16072/90 and 16073/90, 18 September 2009, para 224; and Al-Skeini and Others $v$ UK, Application No 55721/07, 7 July 2011, para 182.

58 Cf. Joint Partly Dissenting Opinion of Judges Villiger, Steiner, Power-Forde, Lemmens and Grițco in Del Rio Prada v Spain, Application No 42750/09, 21 October 2013. 
acknowledge them as victims who could claim reparations. The Peruvian government instead directed the court to place such violations in the 'context' of an 'extremely serious situation of internal conflict', with reparations to be determined in line with domestic policies. ${ }^{59}$ The Inter-American Court rejected the state's claims, awarding substantial compensation to victims and their next of kin, as well as ordering the state to effectively investigate the violations, provide medical and psychological assistance, publicly acknowledge the state's responsibility through a public ceremony broadcast by the media, include the names of those killed in the prison on the 'Eye that Cries' memorial, and educate state forces on human rights norms to prevent future violations. ${ }^{60}$

In subsequent proceedings, the Peruvian government sought clarification of this decision on the grounds that the victims, as members of the Shining Path, were responsible for committing serious violations of the human rights of other Peruvians and the court therefore needed to respect the memory of those they had victimised. Moreover, the Peruvian government argued that the provision of substantial compensation to members of the Shining Path as victims by the court could allow them to continue their 'subversive' campaign through new violent acts. Instead, the Peruvian government sought the court's approval to offset the victims' compensation as part of their debt to those they had victimised as identified in their criminal convictions. ${ }^{61}$ This stance of the Peruvian government reflected both the need to acknowledge such violations and 'innocent' victims' suffering, as well as to provide a more contextual understanding that those before the court were members of an armed group who were responsible for committing numerous atrocities. ${ }^{62}$

In response, the Inter-American Court refused to mitigate or bar such compensation to the victims on the grounds that, as a human rights court, it lacked the power to determine the nature and aggravating circumstances of the criminal acts of the victims, distinguishing it from a criminal court and determinations of individual criminal responsibility. ${ }^{63}$ Rather, the jurisdiction of the court was to examine the international responsibility of the Peruvian state in fulfilling its obligations under the American Convention, which could not be mitigated by the actions of the victims, owing to the serious nature of the violations. By acknowledging members of Shining Path as victims and deserving of reparations, the court refuted the Peruvian government's suggestions that these victims as terrorists were outside the protection of the law, as well as affirming the serious wrongdoing by the state against these individuals.

Since 2014 the Inter-American Court has taken a more conservative view, limiting or excluding victimised members of non-state armed groups from certain forms of reparations. In the Palace of Justice v Colombia case, the Colombian government disappeared a number of suspects after the terrorist group M-19 attacked the highest court in Bogotá to destroy evidence against narco-traffickers. ${ }^{64}$ At least 94 people were killed, including 11 Supreme Court judges, along with 11 further suspected members of M-19, mostly

59 Miguel Castro Castro Prison v Peru, Merits, Reparations and Costs, Judgment 25 November 2006, Series C No160, paras 135 and 142.

$60 \$ 60,000$ for those 41 individuals killed, and $\$ 22,000-\$ 45,000$ for those survivors who were injured. Ibid paras 410-69.

61 Miguel Castro Castro Prison v Peru, Interpretation of the Judgment on Merits, Reparations and Costs, Judgment 2 August 2008, Series C No 181, paras 29-30.

62 See Root (n 35).

63 Castro Castro Prison (n 59) para.40.

64 Case of Rodriguez. Vera et al (The Disappeared from the Palace of Justice) v Colombia, Preliminary Objections, Merits, Reparations and Costs, Judgment of 14 November 2014. 
cafeteria workers, disappeared by the Colombian army, including Irma Franco Pineda, a law student and member of M-19. The Colombian government argued that Irma should be ineligible for reparations and would be barred from any compensation in domestic law. ${ }^{65}$ However, the court ruled that the family of Irma should receive $\$ 5000$ for pecuniary damage, but no compensation for the moral harm caused. In comparison, other victims not affiliated with $\mathrm{M}-19$ received $\$ 35,000-\$ 48,000$ pecuniary compensation and \$70,000-\$100,000 for moral harm. 66

Similarly, in the case of Cruz Sanchez and Others v Peru, another hostage crisis by the terrorist group MRTA ended with a raid by Peruvian special forces where 14 died, including 11 of the MRTA hostage-takers. ${ }^{67}$ The Inter-American Court found that the Peruvian commandos had extrajudicially executed at least three members of MRTA who had surrendered, including Eduardo Cruz Sanchez. The families of those killed did not ask for pecuniary damages, but did seek moral damages. The court held that it was inappropriate to order compensation in this case and that rehabilitation and publication of the judgment against Peru would be sufficient. ${ }^{68}$ Judge Pérez, partially dissenting, believed that the family of Eduardo should have been eligible for compensation, given the serious harm caused to the family. ${ }^{69}$ Judge Mac-Gregor Poisot, concurring with the judgment, held that the exclusion of the family members of MRTA from compensation could be discriminatory, but did not go as far as to say that monetary awards should be made for Eduardo. ${ }^{70}$ These decisions can be read in light of the political context of the Inter-American Court finds itself, were decisions like Miguel Castro Castro caused uproar and protest in Peru, with the Peruvian government threatening to leave the court's jurisdiction. Moreover, unlike earlier cases, the Inter-American Court failed to provide any reasons for these distinctions.

It is apparent that the issue of reparation for victimised members of terrorist groups remains highly controversial even with international human rights courts, which are premised on redress for violations and non-discrimination. In most cases, victimised perpetrators are excluded or have their reparations limited, due to the unlawful nature of their organisations and actions. This article argues that members of paramilitary or terrorist groups who have been unlawfully killed or seriously injured should be eligible for some form of reparations. Part of the rationale for this is that, by excluding such individuals from reparations we may create three inter-related problems: (1) contribute to narratives that victim-perpetrators deserved such suffering, or such violence was justified, and deny redress for serious violations; (2) prevent the application of reparations to vulnerable or marginalised groups, who resort to violence against the more powerful state, weakening the purpose of reparations to effectively remedy harm; and (3) undermine long-term prospects of peace by leaving certain categories of suffering unaccounted for and unresolved, risking the recurrence of such violence in the future. ${ }^{71}$ It is worth now turning to discuss the Northern Ireland experience of tackling this issue and current proposals in the pension Bill for seriously injured victims.

65 Judgment of the Council of State of 11 September 1997, in the proceedings instituted by the next of kin of Irma Franco Pineda. Rodríguez Vera (n 64) paras 587 and 594.

66 Rodríguez Vera (n 64) paras 591-604.

67 Cruz. Sánchez et al (Japanese Embassy Siege) v Peru, Preliminary Objections, Merits, Reparations and Costs, Judgment of 17 April 2015, Series C No 292.

68 Ibid para 483-85.

69 Ibid partially dissenting opinion of Judge Alberto Pérez Pérez, para 4.

70 Ibid concurring opinion, para 23.

71 Bouris (n 17) 75. Report on Reparations by the Special Rapporteur on the Promotion of Truth, Justice, Reparation and Guarantees of Non-recurrence, Pablo de Greiff, A/69/518, 8 October 2014, para 20. 


\section{The Northern Ireland experience with reparations}

Different forms of reparations have been used to address some of the harm caused by the Troubles in and around Northern Ireland. ${ }^{72}$ However, as mentioned at the beginning of this article, these measures have been somewhat inconspicuous given their piecemeal or inadequate effect in remedying victims' harm. Successes have included the recovery of the remains of individuals disappeared by republican groups. ${ }^{73}$ Yet, most victims have had to rely on claiming compensation through the courts or compensation agencies, or are dependent on services which have inadequately redressed their suffering. It is useful to first briefly outline some of these financial provisions to victims, before discussing in more depth the proposed pension for seriously injured victims.

\section{PAST AND CURRENT FINANCIAL SUPPORT TO VICTIMS}

Some victims have been able to obtain compensation through the courts and the Criminal Injuries Compensation Scheme, which as an administration programme provided monetary awards to victims based on common law equity principles determined by the courts. ${ }^{74}$ However, this scheme did not acknowledge victims' pain or loss or bereavement and court orders were only accessible to those who could afford a lawyer. ${ }^{75}$ Only in 1988 did a bereavement payment become available to spouses and parents of those killed. ${ }^{76} \mathrm{It}$ was replaced in 2002 by a tariff scheme, where the Compensation Agency would determine the amount of compensation on a statutory basis, removing the discretion of the court, and allowing appeals of compensation awards by an independent panel. ${ }^{77}$ In addition, the 2002 tariff scheme also included that compensation was to be calculated 'to acknowledge the grief and sorrow caused by the death of that person and the loss of that person's care, guidance and society'. ${ }^{78}$ Bloomfield reports that from 1969 until 31 March 1998 the Compensation Agency had paid out some $£, 186 \mathrm{~m}$ to victims of terrorist violence in Northern Ireland, with $f, 26 \mathrm{~m}$ paid to relatives of those killed, and $f, 160 \mathrm{~m}$ to those injured. ${ }^{79}$ Although this is a substantial amount of money, as there were over 3600 people killed and over 40,000 injured, these amounts would be inadequate in the long term averaging a few thousand to each victim. Compensation amounts awarded under these schemes or awarded by the court were often seen as insufficient as they were based on income rather than need, i.e. relatives of those killed in the 1970 s were only awarded a few hundred pounds. ${ }^{80}$

The compensation schemes have been more substantively criticised. Families of those paramilitaries killed during the conflict have been denied compensation due to their relative's membership of an unlawful organisation or engagement in terrorist activities at

72 See Patricia MacBride, Reparations in Northern Ireland: A Duty to Victims? (CVS 2011).

73 See Kieran McEvoy and Heather Conway, 'The Dead, the Law, and the Politics of the Past' (2004) 31(4) Journal of Law and Society 539-62.

74 See Criminal Injuries (Compensation) (Northern Ireland) Order 1977.

75 MacBride (n 72) 4.

76 Criminal Injuries (Compensation) (Northern Ireland) Order 1988, s 9.

77 Criminal Injuries Compensation (Northern Ireland) Order 2002.

78 Ibid s 4(2)(d).

79 Sir Kenneth Bloomfield, We Will Remember Them: Report of the Northern Ireland Victims Commissioner (TSO Northern Ireland 1998) para 5.6.

80 Report of the Consultative Group on the Past (CPG 2009) 91; and Marie Breen-Smyth, The Needs of Individuals and their Families Injured as a Result of the Troubles in Northern Ireland (WAVE 2012) 10. 
any time in the past or present. ${ }^{81}$ This exclusion also denied compensation to the relatives of those paramilitaries who had served their sentences and were subsequently killed on release. ${ }^{82}$ This is further complicated by numerous other individuals who were never convicted being able to claim compensation. Victims who were injured also faced their compensation being cut after 16 years, despite their deteriorating health and increasing dependency as they become older. ${ }^{83}$ In addition, victims' life expectancy was underestimated and, as they were unable to work as result of their injuries, the compensation awarded affected their subsequent state benefit allowances. ${ }^{84}$ On a more theoretical level, compensation schemes are not purely reparations as they equate violence during the conflict with ordinary crime, rather than awarding further damages for the sectarian motivation behind the crime. Furthermore, compensation schemes are based on 'social solidarity' that acknowledges that the harm victims suffered was morally wrong, but without any judgment on responsibility (whether provided independently or by those responsible). ${ }^{85}$

The Bloomfield report on victims of the conflict identified a number of problems with the compensation available and recommended that funding be secured for victims and survivors. The Northern Ireland Memorial Fund (NIMF) was subsequently established in 2001. The NIMF provided financial assistance to victims and survivors who had lost a spouse or partner, were seriously injured or were primary carers, through eight grants covering short breaks, chronic pain management, disability allowance, education and training, and other allowances. 86 The NIMF was originally established as a benevolent fund, but in 2010 it changed to a conditional means-tested scheme due to financial constraints. In 2012/2013 the budget of the NIMF was $£, 3,304,250$ for 2869 potential applicants. ${ }^{87}$ From 2001-2012 some 11,000 victims and survivors availed themselves of the fund and were awarded some $f, 17 \mathrm{~m} .{ }^{88}$ Considering the number of victims of the conflict, the fund only helped a fraction of those affected. Yet, the NIMF was an important source of funding for those who did avail themselves of it, considering their financial and social hardship. In April 2012, as part of the Stormont executive's tenyear Strategy on Victims and Survivors, the NIMF ${ }^{89}$ was subsumed within the newly created Victims and Survivors Service (VSS), with an allocated $f_{36 \mathrm{~m}}$ annual budget, which is intended to coordinate and fund the provision of services to victims, including counselling, befriending, respite breaks, chronic pain management and retraining

81 Criminal Injuries (Compensation) (Northern Ireland) Order 1977, s 6(3); and Criminal Injuries (Compensation) (Northern Ireland) Order 1988, s 5(9). MacBride (n 72) 4. This has been only recently changed in 2009 under the New Criminal Injuries Compensation Scheme, which allows the Secretary of State to reduce or refuse any award based on the actions of the claimant (para 14).

82 MacBride (n 72) 4.

83 Ibid; and Breen-Smyth (n 80) 9.

84 MacBride (n 72) and Breen-Smyth (n 80).

85 Katherina Buck, 'State Compensation to Crime Victims and the Principle of Social Solidarity: Can Theoretical Analysis Contribute to a Future European Framework' (2005) 13(2) European Journal of Crime, Criminal Law and Criminal Justice 148-78.

86 MacBride (n 72).

87 CVS, Comprehensive Needs Assessment (CVS 2012) 18.

88 Ibid 60. Similarly, in the Republic of Ireland, the Remembrance Commission between 2003 and 2008 provided $€ 3.9 \mathrm{~m}$ to victims and survivors as well as over $€ 2 \mathrm{~m}$ for support services to victims within the country; see MacBride (n 72) 4.

89 Along with the Trauma Advisory Panels and the Community Relations Council Victims Unit. 
schemes. The VSS, since its establishment in 2013, has been criticised for its intrusive individual needs assessments and delays in funding to groups. ${ }^{90}$

Currently, a service-based approach dominates provision for victims' and survivors' needs. As a result of the Good Friday Agreement and subsequent reports into assistance for victims, funds were established to support victims through numerous groups, representing different areas, constituents and political opinion. ${ }^{91}$ Beneficiaries of such schemes are based on the broad definition of the Victims and Survivors (Northern Ireland) Order 2006 of a victim as: 'someone who is or has been physically or psychologically injured, [provides a substantial amount of care for such a person, or bereaved] as a result of or in consequence of a conflict-related incident'. ${ }^{92}$

The inclusive nature of the definition was intentional to avoid contention over eligibility for service provision, reflecting more humanitarian concerns over addressing harm than accountability. ${ }^{93}$ As such, victimised perpetrators can and do access services through the VSS and the Commission for Victims and Survivors (CVS) can advocate on their behalf as victims. However, the future of such support to victims is dependent on budgetary allocations by the Office of the First and Deputy First Minister, making such provision discretionary without any long-term commitment. ${ }^{94}$ In terms of accountability, such measures do not publicly acknowledge individuals as victims, as service provision loses the recognition, entitlement and responsibility aspects associated with reparations through their delivery by groups. In terms of remedy, services provided have been criticised for their access issues, location, standard of provision and ability to respond to victims' needs. ${ }^{95}$

In 2009 the Consultative Group on the Past (CGP) came closer to providing more inclusive reparations that acknowledged victims' harm and offered something close to an appropriate amount of compensation to those families bereaved. ${ }^{96}$ Basing its conclusions on the operation of a similarly inclusive scheme in the Republic of Ireland, the CGP recognised the shortcomings of compensation for the harm caused by the conflict and recommended that a 'one-off ex-gratia recognition payment' of $f, 12,000$ be paid to the relatives of those killed during the conflict, to acknowledge the loss they have endured. ${ }^{97}$ The language of ex gratia is important as it implies that such a payment is charitable, rather than based on any legal obligation, identifiable responsible actor or entitlement for such victims to a remedy. Nonetheless, this one recommendation proved politically controversial, as family members of terrorists who were killed would also receive money, arguably equating their suffering with those of 'innocent' civilian victims. Moreover, an overlooked issue was that this payment excluded those who had been seriously injured. As a result of the recognition payment recommendation, the whole report was rejected,

90 See WKM Solutions, The Victims and Survivors Service: An Independent Assessment (WKM 2014); and Chartered Institute of Public Finance and Accountancy (CIPFA) (CIPFA 2014) 9.

91 Principle 12, Part 6, Rights, Safeguards and Equality of Opportunity, Good Friday/Belfast Agreement 1998. See Bloomfield (n 79).

92 Victims and Survivors (Northern Ireland) Order 2006, s 3.

93 Services for Victims and Survivors (Northern Ireland Office 2005) 6.

94 Recent reviews initiated by the CVS have found more systemic problems with the funding and assessments carried out by the VSS. See WKM Solutions (n 90) and CIPFA (n 90).

95 See Interim Victims Commissioner, Services for Victims and Survivors: Addressing the Human Legacy (2007); and CVS reports WKM Solutions (n 90) and CIPFA (n 90).

96 See Cheryl Lawther, Truth, Denial and Transition: Northern Ireland and the Contested Past (Routledge 2014).

97 CPG (n 80) 92. A similar payment was made by the Irish government through its Remembrance Commission's Acknowledgement Payment. 
despite its comprehensive proposals on addressing truth and justice. Discussions on the past since 2009 have been muted on reparations, with only the issue of the pension for seriously injured victims gaining traction since 2014 .

\section{A PENSION FOR SERIOUSLY INJURED VICTIMS}

The most recent proposal on providing some form of reparations has come in the form of a pension for seriously injured victims. It is based on the research of Breen-Smyth that identified the needs of those seriously injured and their lack of a pension, through being unable to work. ${ }^{98}$ As a result, WAVE and its associated injured victims group have advocated for a pension, ${ }^{99}$ which position has been endorsed by the CVS. ${ }^{100}$ The proposed pension for those seriously injured serves to acknowledge the harm endured and alleviate their daily suffering by providing them financial security in the old age. The number of those eligible is likely to be less than 500 with most averaging a 50 per cent rate of pension based on the level of their disablement, in turn based on data collected by WAVE from the NIMF and payments made through the VSS.

Other countries have adopted similar pensions, such as Spain which has a comparatively generous scheme for those victimised by terrorism - a monthly payment of approximately $€ 1600$ per month - but excludes members of terrorist organisations. ${ }^{101}$ Similarly, in Chile, monthly pensions, access to specialist healthcare and educational scholarships have been provided to survivors of torture and political imprisonment. ${ }^{102}$ WAVE recommends that the pension should be based on the following principles: noncontributory; non-means-tested; completely disregarded for the purposes of calculating entitlement to means-tested benefits; with the level of payments graded to reflect the differing levels of disablement that those injured in the Troubles experience; and should continue beyond state retirement age. ${ }^{103}$ These measures are meant to ensure the pension is easy to administer, as there is no need to develop rules around contribution conditions or to assess the applicant's wealth. ${ }^{104}$

To reflect reparation principles in human rights law and the recent report by the UN Special Rapporteur (UNSR) on the promotion of truth, justice, reparation and guarantees of non-recurrence, The UNSR Pablo de Greiff, noted that the pension should also have a dedicated budget line. ${ }^{105} \mathrm{~A}$ pension by itself is not enough and UNSR Greiff stipulated that such measures need to be accompanied by other measures, such as rehabilitation, measures of satisfaction and guarantees of non-repetition. The Inter-American Court of Human Rights and the UNBPG on the Right to Remedy and Reparations support this on the grounds that compensation by itself cannot redress the public and moral harm

98 Breen-Smyth (n 80).

99 Wave Trauma Centre is a cross-community organisation formed in 1991 to support those bereaved, injured or traumatised during the Troubles.

100 CVS, A Pension for People Severely Injured in the Troubles, Commission Advice Paper (CVS 11 June 2014.

101 Stuart Magee, Exploring Models for the Proposal of Special Pension Provision for those Injured in the Northern Ireland 'Troubles' (WAVE Trauma Centre 2013) 5. Based on Law 21/1986, 23 December 1986. The more recent law would exclude members of state assassination squads such as Grupos Antiterroristas de Liberación, Article 4(3), Law 2/2003 of 12 March 2003, amending Law 32/1999 of 8 October 1999 of solidarity with the victims of terrorism.

102 'Valech Reparations': Law 19.992 of 24 December 2004.

103 Magee (n 101) 2-3.

104 Ibid 3.

105 de Greiff (n 71) para 56. 
suffered by victims. ${ }^{106}$ The comprehensiveness of any proposed pension will inevitably confront the challenge of determining the eligibility of victims. The experience of the CGP's recognition payment suggests that any sort of payment based on harm suffered during the Troubles is likely to be polemic. Even before the draft legislation has been introduced to the Northern Ireland Assembly, headlines in the local newspapers have read 'Disabled ex-terrorists may get $f_{1} 150$-a-week pension'107 (with a picture of a man in a balaclava with a rifle) and 'Pensions for IRA - but not for IRA's victims'. ${ }^{108}$ The following section proposes a number of avenues to navigate the difficulties of eligibility and of defining who is a victim for the purposes of the proposed pension.

\section{Finding a way forward on victim eligibility in Northern Ireland}

This section identifies three avenues: a non-discriminatory approach; a review panel; and a private trust fund. It also suggests ways of defining who is eligible with some clarity and some remaining challenges for such a pension scheme. ${ }^{109}$

\section{A NON-DISCRIMINATORY APPROACH}

The current service provision to victims and survivors makes no distinction between civilians, members of the security forces or paramilitaries who seek to access services and secure individual assistance payments. This non-discriminatory approach is consistent with human rights law that everyone should have access to effective remedy for serious injury or death. As discussed above, even regional human rights courts do not have consistent jurisprudence on the eligibility of claimants for reparations who are members of non-state armed or terrorist groups. The Victims and Survivors (NI) Order 2006 definition of victims and survivors is quite broad and inclusive. However, this definition is inapplicable for constructing a pension programme for seriously injured victims in Northern Ireland as it is specifically stipulated to be construed in terms of the work of the CVS in advocating for victims' interests. In more practical terms, in order for reparations to be feasible and include a meaningful amount, it is necessary to consider those who suffer the most and continue to feel harmful effects, such as injured victims. Such a wide definition under the 2006 Order would make a large victim population eligible, diluting the amount and proportion available for those who suffer

106 Blake v Guatemala, Reparations, Series C No 48, 22 January 1999, para 42; and Principle 18, UNBPG on the Right to a Remedy and Reparation for Victims of Gross Violations of International Human Rights Law and Serious Violations of International Humanitarian Law, A/RES/60/147, 16 December 2005.

107 Belfast Telegraph (Belfast, 19 March 2015).

108 Belfast Telegraph (Belfast, 15 June 2015).

109 These models have been developed following a process of sustained engagement with victim groups, government officials and other key stakeholders on appropriate responses to deal with victimised-perpetrators on the issue of a pension for seriously injured victims. That process of engagement involved me writing a number of blogs, a policy paper and briefings for political parties, government officials and the Victims Forum around the Haass-O'Sullivan talks in 2013 and the Stormont House Agreement talks in 2014. This was facilitated through my role as a Research Fellow on the Arts and Humanities Research Council (AHRC) funded project 'Amnesties, Prosecutions and the Public Interest in the Northern Ireland Transition' led by Professor Kieran McEvoy (AH/J013897/1). Although the project focused on truth and justice, drawing from my own research it became apparent that the issue of reparations was being neglected and under the guidance of Professor McEvoy I began to explore how this could be approached through the networks built up through the AHRC project. The project also funded a conference on reparations with keynote speaker Judge Cançado Trindade, former Presiding Judge of the Inter-American Court of Human Rights. See Luke Moffett, Report on the Remedying the Past, Healing for the Future Conference Report (CVS November 2014); Luke Moffett, 'Time for a Pension for those Seriously Injured during the Troubles' (Slugger O’Toole, 3 December 2014); and Luke Moffett, 'A Pension for those Seriously Injured: Reparations for Dealing with the Past in Northern Ireland?' (Rights NI, 1 and 2 June 2015). 
the most. That said, if the Victims and Survivors (NI) Order 2006 were adopted for seriously injured victims based on those who suffer disablement, it would provide a nondiscriminatory approach.

Similarly, in private law, which provides the basis for reparations in international law, there are a number of principles for dealing with claims on the part of those who have both been responsible for inflicting harm and victims of harm. In equity the 'clean hands' doctrine, volenti non fit injuria, prevents an individual from deriving a profit from their own wrong. ${ }^{110}$ The rationale for this doctrine is to ensure in the public interest that 'no polluted hand shall touch the pure foundations of justice' by excluding from claiming redress those who have committed wrongs. ${ }^{111}$ As such, responsibility for the harm is supposed to be balanced between the parties in determining liability and causation of the injury. ${ }^{112}$

Perhaps more applicable is torts law, in particular trespasses against the person (such as battery), with the two principles of illegality and contributory negligence which place limits on individuals' ability to claim damages where they are responsible for their own or others' suffering. For the first of these, illegality is based on the defensive principle of ex turpi causa non oritur actio that no action can arise for an individual who engages in an immoral or illegal act. This rule is again based on public policy to prevent a person from profiting from their wrongdoing. ${ }^{113}$ Nonetheless, the defence of illegality has been held inapplicable to claims of trespass against the person. ${ }^{114}$ This exception is on the grounds that individuals should not be excluded from the protection of the law, as to do otherwise would undermine the integrity of the legal system and access to redress for serious harm. ${ }^{115}$ However, the courts will take into account the claimant's illegal conduct in his or her own suffering that is so 'inextricably linked' with that claimant's own 'criminal or illegal conduct that the court could not permit him to recover without appearing to condone that conduct'; in other words, an individual cannot claim redress if they have suffered from their own hand, reflecting a distinction between internal and external causation of harm. ${ }^{116}$ That said, the courts do take a more pragmatic approach based on the facts of the case and public policy, moving away from moral responsibility in terms of the historical immorality or 'public consciousness test'. ${ }^{117}$

In light of the pragmatic approach to illegality in this context, the courts' ability to determine the responsibility or fault of a claimant turns more on their contributory negligence. This rule distinguishes between a claimant's right to claim a remedy, if they suffer damage both as a result of their own fault and the fault of another person, but it does not debar them from claiming damages. However, it does allow a defendant a defence to reduce the damages available on 'just and equitable' terms on the basis of the

110 Nullus commodum capere potest de sua injuria propria, 'he who has committed iniquity shall not have equity', Tinsley $v$ Milligan [1993] UKHL 3, 12.

111 Collins v Blantern (1767) $2 \mathrm{~KB} 347,350$.

112 Lisa J Laplante, 'The Law of Remedies and the Clean Hands Doctrine: Exclusionary Reparation Policies in Peru’s Political Transition' (2007) 23(1) American University International Law Review 51-90, 60.

113 See Standard Chartered Bank v Pakistan National Shipping Corporation [2000] 1 Lloyd's Rep 218, [232]; and James Goudkamp, 'Ex turpi causa and immoral behaviour in the tort context' (2011) 127(July) Law Quarterly Review 354-58.

114 Law Reform Commission (LRC), The Illegality Defence: A Consultative Report CP No 189 (LRC 2009) 128-30

115 Revill v Newbery [1996] QB 567. See Rick Glofcheski, 'Plaintiff's Illegality as a Bar to Recovery of Personal Injury Damages’ (1999) 19(1) Legal Studies 6-23, 20.

116 Cross v Kirkby, The Times (London 5 April 2000); affirmed in Gray v Thames Trains Ltd and Network Rail Infrastructure Ltd [2008] EWCA Civ 713, see Lord Hoffman [29].

117 As per LJ Bingham, Saunders v Edwards [1987] 1 WLR 1116, 1134. See LRC (n 114) 140-42. 
claimant's share of their responsibility in the damage. ${ }^{118}$ At least in the UK, contributory negligence is not applicable to trespasses against the person, on the basis that such harm is criminalised on public policy grounds, as according to Glanville Williams, it is a 'penal provision aimed at repressing conduct flagrantly wrongful' as well as being the 'result of the ordinary human feeling that the defendant's wrongful intention so outweighs the [claimant's] wrongful negligence as to efface it altogether'. ${ }^{119}$ Accordingly, when it comes to trespasses against the person, the courts are very reluctant to prevent individuals from being able to seek damages as a remedy for serious harm in the form of personal injury, regardless of their background or past conduct. This is apparent in the case of Aidan McKeever, a getaway driver in an IRA attack on the police station in Coalisland in 1992. He was successful in suing the Ministry of Defence for injuries suffered in the course of an ambush by the SAS which killed four other IRA members. The High Court found that the SAS was not justified in shooting him and upheld the award of $f_{75,000.120}$ The Ministry of Defence raised the defences of volenti non fit injuria, ex turpi causa non oritur actio and contributory negligence, but these were all rejected by the court. This decision may not vindicate a non-discriminatory approach, but rather the failure of the Ministry of Defence to satisfy the evidential burden in proving the defences. As such, private law, human rights courts (to some extent) and the Victims and Survivors (NI) Order 2006 all recognise a non-discriminatory approach for defining victims and, with the former two, for compensation.

\section{A REVIEW PANEL}

An alternative approach to ensure the expediency of claims of civilians who were seriously injured would involve provision for a review panel. This could be built into the pension legislation to determine whether victimised perpetrators should be eligible based on their circumstances. Such a review panel is provided for under the Civil Service (Special Advisers) Act (Northern Ireland) 2013, which was a Private Members' Bill brought forward to exclude convicted members of paramilitary groups from being employed as special advisors to Northern Ireland government ministers. The 2013 Act review panel can determine whether those convicted of a 'serious criminal conviction'121 can be eligible for a special adviser position taking into account:

(a) whether the person has shown contrition for the offence to which the serious criminal conviction relates,

(b) whether the person has taken all reasonable steps to assist in the investigation and prosecution of all other persons connected with the commission of the offence,

(c) the views of any victim of the offence, or where a victim has died, the views of any close family member of the victim. ${ }^{122}$

For the purposes of the pension Bill, the panel could take into account the time victimised perpetrators served in prison, the gravity of their offence(s), their disability and the impact of their serious injury on daily life. There should also be provision for appeal to a High Court judge if an individual is unhappy with the outcome of the review

118 Law Reform (Contributory Negligence) Act 1945, 1(1).

119 Glanville L Williams, Joint Torts and Contributory Negligence: A Study of Concurrent Fault in Great Britain, Ireland and the Common-law Dominions (Wildy 1951) 197-98; and Co-operative Group (CWS) Ltd v Pritchard [2011] EWCA Civ 329, para 37.

120 Aidan McKeever v Ministry of Defence [2011] NIQB 87.

121 Article 5. Generally a sentence of over five years.

122 Article 3(5), Civil Service (Special Advisers) Act (Northern Ireland) 2013. 
panel. ${ }^{123}$ Alternatively, an appeals process could be built into legislation to avoid costly litigation and to provide prompt hearings before a single sitting judge.

Another option would be for a review panel that could assess the extent of the person's harm against their responsibility. Individuals who were victimised members of non-state armed groups could be included in the pension scheme, but their payments could be reduced by a proportionate amount to reflect their past responsibility in victimising others. In some domestic criminal injury compensation schemes individuals can be barred or limited to claiming certain amounts of compensation, as can their family members, based on the direct victim's background, association or past conduct. ${ }^{124}$ Given their moral basis, criminal injury compensation schemes generally award compensation to 'good citizens', i.e. 'ideal' victims. ${ }^{125}$ By way of example, in Northern Ireland the amount of compensation can be reduced or withheld based on: the individual's conduct before, during or after the incident; the individual's failure to inform or cooperate with the police; their 'character' based on their criminal convictions; or the minister's discretion that such an award would be inappropriate. ${ }^{126}$ The basis of excluding or limiting compensation to victimised perpetrators is to reflect the belief that such persons who have committed offences in the past have:

... probably caused distress and loss and injury to other persons, and [have] certainly caused considerable expense to society by reason of court appearances and the cost of supervising sentences, even when they have been non-custodial, and the victims may themselves have sought compensation, which is another charge on society. Even though a victim may be blameless in the incident in which the injury was sustained ... 127

Accordingly, victimised perpetrators are not automatically excluded from claiming compensation. However, their amount of compensation can be reduced through a series of penalty points depending on the length of their conviction and the time since their release; as well as the gravity of the claim in relation to the claimant's criminal background. ${ }^{128}$ Thus, mitigating a victimised perpetrator's claim for compensation, or more broadly reparations, could reflect their responsibility, both internally in the harm they caused themselves and externally through harm caused to others. The scaled system of reducing their compensation could evince retribution through ensuring that their responsibility is proportionally reflected in their final award. Yet, allowing them access to reparation acknowledges their suffering and that they deserve some form of remedy, meaning that their past actions should not bar them from the protection of the law. In Northern Ireland at least, this compensation was restructured in part for this purpose, due to previous schemes denying compensation to the families of those paramilitaries

123 As in the Civil Service (Special Advisers) Act (Northern Ireland) 2013, Article 4.

124 Articles 8 and 9(4), Convention on the Compensation of Victims of Violent Crimes, 24 November 1983.

125 David Miers, 'Compensating Deserving Victims of Violence Crime: The Criminal Injuries Compensation Scheme 2012' (2014) 34(2) Legal Studies 242-78, 251 and 258.

126 Paras 14(1) and 16 (for those killed). An award can be inappropriate and withheld if it is likely that the assailant would benefit, para 17 (a).

127 Compensation Services, Guide to the Northern Ireland Criminal Injuries Compensation Scheme (Department of Justice 2009) para 8.15.

128 By way of example, if an individual was convicted of murder more than 10 years ago, their claim for compensation for contemporary injury would be reduced by 25 per cent. See Compensation Services (n 127) 21. 
unlawfully killed by private or state actors. ${ }^{129}$ This approach reflects that such individuals are both responsible in victimising others, but, due to the seriousness of their suffering, they should have some form of remedy.

\section{PRIVATE TRUST FUND}

To avoid the pension Bill handing a 'terrorist' a monthly government cheque, a private trust fund could be established as part of the pension Bill for those seriously injured individuals who were members of paramilitary groups. Those 'innocent' victims who suffered serious injuries would automatically receive their pension from the government. However, those victimised perpetrators would receive a comparable amount through the private trust fund, allowing them access to a pension as a victim without attaching government money to it. Such funds could come from private charitable donors, international organisations, or even prisoner groups to ensure that they 'look after their own'.

In South Africa a separate pension fund was set up for members of former state and non-state armed groups, such as the African National Congress military wing (MK), on the basis of the sacrifices such forces made in the establishment of democracy. ${ }^{130}$ The pension board in determining awards could take into account the individual's role and motive in a political offence and its nature and gravity with regard to state and non-state actors. ${ }^{131}$ The International Criminal Court has a Trust Fund for Victims (TFV) which has two mandates: to provide assistance to victims; and to act as a financial repository and provider of reparations where perpetrators are indigent. ${ }^{132}$ Although the TFV is not set up to avoid difficult issues of victimised perpetrators, it is providing reparations to child soldiers in the Lubanga case, as the convicted person is indigent. In the Northern Ireland context, it may be difficult for such groups to fund-raise such money and may not be palatable to victimised perpetrators as it concedes that there is a hierarchy of victims. Thus, the first two models seem more viable. Beyond these avenues to craft an equitable solution for victimised perpetrators and 'innocent victims', defining who is eligible will be key.

\section{DEFINING WHO IS ELIGIBLE}

The definition of which victims are eligible for the pension has to be carefully crafted so as to be clear and to achieve a reasonably equitable solution for all affected victims. There are four possible grounds for defining eligibility: inclusive; unlawful harm; serious criminal convictions/scheduled offences; and qualified. With the first of these, WAVE and the CVS have suggested an inclusive approach in their guidance on the pension as:

129 Kenneth Bloomfield, Report of the Review of Criminal Injuries Compensation in Northern Ireland (TSO 1999). The report recognises that individuals may reform over time and dissociate themselves from their previous way of life' reflecting that their agency and responsibility for past conduct should not deny recognition of their victimisation.

130 Including the South African Defence Forces, Umkhonoto we Sizwe and the Azanian People's Liberation Army, recognising that members did not join liberation movements for financial compensation, but that they were prevented from accumulating a work pension. Some members of MK believed that victims who 'did not fight' did not deserve compensation. Lovell Fernandez, 'Reparations Policy in South Africa for the Victims of Apartheid' (1999) 3(2) Law, Democracy and Development 209-22, 214. S 189(1) of the Interim South African Constitution (No 200 of 1993); s 1, Government Employees Pension Law 1996 (No 21 of 1996); and Special Pensions Act 1996 (No 69 of 1996).

131 Special Pensions Act 1996, s 1(2).

132 Article 79. See Luke Moffett, 'Reparative Complementarity: Ensuring an Effective Remedy for Victims in the Reparation Regime of the International Criminal Court' (2013) 17(3) International Journal of Human Rights 368-90. 
a) The claimant suffered physical injury(s) as a result of Troubles related incident(s);

b) the injury(s) has resulted in disablement. ${ }^{133}$

This inclusive approach reflects that anyone who suffered serious violations should have access to a remedy, compliant with the non-discrimination principle in human rights law, no matter their background. It also reflects the broad definition under the Victims and Survivors (NI) Order 2006. Moreover, this inclusive definition does not tackle the issue of ex-combatants who were responsible for victimising others but ended up themselves suffering serious injuries. There are perhaps other ways of crafting a legal definition to address these individuals.

The second option of unlawful suffering is to define eligibility as:

a) The claimant suffered physical injury(s) as a result of Troubles related incident(s), which was unlawfully caused by another person or organisation;

b) the injury(s) has resulted in disablement.

This would allow a broad category of individuals to be eligible for the pension, but would implicitly exclude those who injured themselves (such as bomb-makers) or were lawfully shot by the security forces. This is compliant with the judgment in the aforementioned Aidan McKeever $v$ Ministry of Defence where the claimant (an unarmed getaway driver for the IRA) was unlawfully shot and injured (four other IRA members being killed) by the British army in February 1992. ${ }^{134}$ Accordingly, this approach reflects a basic tenet of the rule of law and human rights law that everyone who suffers unlawful intentional harm should have access to a remedy.

The third option is an explicit exclusion of convicted ex-combatants as:

a) The claimant suffered physical injury(s) as a result of Troubles related incident(s);

b) the injury(s) has resulted in disablement;

c) this excludes any person who has been convicted for a serious criminal conviction or scheduled offence.

The definition of serious criminal conviction would follow that used in the Civil Service (Special Advisers) Act (NI) 2013 of a crime that resulted in a conviction with imprisonment of five years or more, which would include most scheduled offences, such as membership of a proscribed organisation. This is consistent with the Rehabilitation of Offenders (NI) Order 1978, where those convicted of offences with imprisonment ordered over five years or life cannot have their sentence rehabilitated or their conviction spent. ${ }^{135}$ However, the difficulty with this exclusion is that not every ex-combatant was convicted and it thus would not exclude every single victimised perpetrator. Moreover, the Criminal Case Review Commission, which examines wrongful convictions, has over 300 appeals pending, most of which are overturning convictions based on improperly obtained confessions. The Iraqi compensation law for those injured during military operations or terrorist offences excludes anyone convicted under the Iraqi terrorism act, 'until proven innocent', which is perhaps a workaround for this issue. ${ }^{136}$

133 Magee (n 101) 3; CVS, A Pension for People Severely Injured in the Troubles Commission Advice Paper (CVS, 11 September 2013) 6.

134 Aidan McKeever v Ministry of Defence [2011] NIQB 87.

135 Article 6.

136 Article 17, 2009 Compensation for those Affected by Military Operations, Military Mistakes and Terrorist Actions, Law No 20. 
The fourth option is a qualified definition of:

a) The claimant suffered physical injury(s) as a result of Troubles related incident(s);

b) the injury(s) has resulted in disablement;

c) any person convicted for a serious criminal conviction or scheduled offence their eligibility will be dealt with through the review panel/their amount will be determined through the tariff system.

This would allow ex-combatants to be distinguished from civilians as responsible actors who were involved in causing suffering to others, but, given the seriousness of their own individual harm caused by others, deserve some form of redress. The benefit with this definition is that it neutralises the issue of eligibility from obstructing the ability of 'innocent' seriously injured victims from obtaining their compensation, as those victimised perpetrators go through the panel or a specialised committee to decide such cases on the basis of a tariff. The experience of Peru is apt, where victimised perpetrators were excluded and checks had to be made with every application whether the person was a member of an insurgent group, which had the effect of delaying for years reparations to all victims. ${ }^{137}$

\section{REMAINING CHALLENGES FOR A SCHEME}

The definition is likely to be the most contentious part of the pension Bill, but there remain other challenges for such a programme. Although the pension law focuses, deservedly so, on those who are seriously injured, other victims who are bereaved or who have suffered sexual violence should have access to some form of reparation, whether compensation or more symbolic measures. While other contexts, such as Sierra Leone, Timor Leste and Kenya, have recommended that reparations be prioritised for victims who are seriously injured and bereaved, such programmes have included tens of thousands of victims and a wide range of violations in order to fully remedy the past rather than particular harms. In the Northern Ireland context, there are also considerations of s 75 of the Northern Ireland Act 1998 on obligations on public authorities to ensure due regard to equality of opportunity to disabled persons. Those victims excluded from the pension, such as those bereaved, may seek to be included through litigation, which may increase the cost and size of the programme if they are successful.

Difficulties will also arise for those injured victims who are required to evidence that their harm was brought about by a Troubles-related incident. Some are likely to have medical evidence, but not all. WAVE proposes receipt of the money for injuries from the NIMF or VSS as one possibility. Alternative arrangements of evidence should be put in place for the CVS to assist victims in evidence collection through public records to ensure greater inclusion of those who are eligible. A further evidential problem, but also important for the focus of redressing which harm, is whether or not those who suffered from psychological trauma as a result of a Troubles-related incident should be eligible. Including those with psychological injuries is likely to increase the number of eligible persons by thousands and reduce the amount of money available to those who suffer from debilitating physical injuries. The Northern Ireland Court of Appeal has held that, in relation to the Criminal Injuries Compensation Scheme, psychological injuries should be included for such a scheme where they are disabling. ${ }^{138}$ However, as there is no

137 Root (n 35) 134.

138 An Application by Florence Hoy for Judicial Review [2009] NICA 7. 
requirement in international law to include psychologically injured victims in pension or reparation laws, such individuals are perhaps better dealt with through the proposed Mental Trauma Service.

\section{Conclusion}

Reparations, while a worthy aspiration in redressing harm, often get bogged down in defining who is eligible and deserving of remedies. This article has attempted to provide some paths across the quagmire of contention around victimised perpetrators. It is important to distinguish reparations from services that are currently used in Northern Ireland, with the former being based on right or legal entitlement, acknowledging the wrongful act of the violence committed against the victim and vindicating their moral worth; whereas services are discretionary, making victims dependents rather than agents. This has important connotations for the framing of the pension Bill for seriously injured victims because work by WAVE and the CVS, which have been pushing the pension, has drawn from the experience of the Employment and Support Allowance Regulations (NI) 2008 or industrial accidents for extent of disablement. Such comparators should be useful in finding an appropriate amount, but this approach was rejected in Argentina where compensation for victims was based on the pay of the highest ranked civil servant rather than the industrial accidents tariff, as such harm, particularly during the Troubles in Northern Ireland, was not accidental, but rather arose from intentional political violence that should carry more serious connotations and more adequate reparations. ${ }^{139}$ Although reparations are usually based on responsibility in international law, it may cause some controversy to base the pension for injured victims in Northern Ireland on such a premise, given that the majority of violence was carried out by paramilitaries. That said, reparations are adopted in many countries with multiple responsible actors where the state takes on the responsibility to make reparations on the ground of social solidarity, with provisions that money paid out to victims is treated as an indemnity against any perpetrators who are later convicted. More problematic is the crafting of a pension law in light of a wider transitional justice programme, including truth recovery and justice mechanisms. But without such complementary accountability mechanisms, such money can be perceived as 'blood money' to pay off certain victim constituents and to give a good news story for politicians coming up to a Northern Ireland Assembly election. As UNSR Pablo de Greiff recently stated:

[in] order for something to count as reparation, as a justice measure, it has to be accompanied by an acknowledgment of responsibility and it has to be linked, precisely, with truth, justice, and guarantees of non-recurrence. Second, and as a consequence, recognizing the distinctive contribution that reparations can make to victims does not justify, either legally or morally, asking them - or anyone else - to trade off amongst the different justice initiatives. ${ }^{140}$

A pension for seriously injured victims has been a long time coming, but resolution of this issue is not only a long overdue opportunity to alleviate the suffering of several thousand victims, it is also an opportunity to acknowledge and unpack the complexity of political violence and associated victimisation.

139 José María Guembe, 'Economic Reparations for Grave Human Rights Violations: The Argentinean Experience' in Pablo de Greiff (ed), The Handbook for Reparations (OUP 2006) 21-54, 30.

140 de Greiff (n 71) para 12. 
